Int. J. Dev. Biol. 52: 237-248 (2008)

doi: $10.1387 / \mathrm{ijdb} .072315 \mathrm{kd}$

\title{
A novel, neural potential of non-hematopoietic human umbilical cord blood stem cells
}

\author{
KRYSTYNA DOMANSKA-JANIK*, LEONORA BUZANSKA and BARBARA LUKOMSKA \\ NeuroRepair Department, M. Mossakowski Medical Research and Clinical Institute, Polish Academy of Sciences, Warsaw, Poland
}

\begin{abstract}
From the time of discovery that among the cord blood mononuclear cell population there are cells capable of changing their fate towards the neural lineage and producing functional neurons and macroglial cells, our attempts have been focused on the understanding of the underlying mechanism of this transition. We have deciphered the first steps of neural stem/ progenitor gene induction in aggregating culture of cord blood mononuclear cells, their rapid phenotypic conversion under the influence of neuromorphogenic signals due to mitogen activation and their ability to expand and develop a prototypic, long-living line with neural stem cell properties. Evidence has accumulated that human umbilical cord-derived and neurally committed cells, due to their capacity for self-renewal, multilineage differentiation, plasticity and ability for long-lasting growth in vitro, provide unique material for the cell therapy of a wide spectrum of neurological diseases. The putative regenerating potential of these cord blood-derived neural stem/progenitor cells was evaluated after transplantation in experimental models of brain injury. In spite of initial promising data, the results indicate an urgent need to improve available animal model protocols in order to increase immuno-tolerance toward transplanted human cells.
\end{abstract}

KEY WORDS: human cord blood, neural stem cell, neurosphere, transplantation, CNS

\section{Introduction}

All cells in the organism are descendants of a single cell - the fertilized egg. The development requires multiplication and differentiation of its descendants into all the different cell types in the body. It is clear that in mammals, various primitive cells - stem cells (the embryo's inner cell mass or cells residing in tissue regenerative niches of organism) may still maintain their expansion and differentiation potentials when propagated in vitro. In the presence of differentiation inhibiting signals they are able to multiply for many cells generations as cell lines or "strains" called embryonic (ESC) or adult (ASC) stem cells. Due to their expansion potential and intrinsic ability to create cells of different properties it is believed that stem cells growing in vitro would provide an ideal transplantation material for regenerative medicine. Moreover, after genetically-aided transformation they can be used as a semi-pharmaceutical product for different clinical applications.

Until recently, the majority of stem cell research was focused on ES cells as those of having hypothetical potency to create any somatic cell type either in vitroor after transplantation in response to local differentiation signals. Apart of practical obstacles to reach these goals, the ethical concern surrounding any technique involving human embryos, even these in pre-implantation stages, indicated the need for finding alternative sources of SC. One appealing option is to bypass creation of ES cells from embryo by "reprogramming" a somatic cell to its undifferentiated state by mimicking events that take place in a somatic nuclear transfer (Wilmut et al., 1997). Moreover, the finding that differentiation associated changes are reversible and controlled by epigenetic status of DNA and chromatin (Tagoh et al., 2004; Ansel et al., 2003; Hsieh and Gage, 2004; Xi and Xie, 2005) can indicate potential ability of any particular somatic cell to change or reverse its already established developmental state through the delivery of appropriate instructive signal(s).

At the beginning of this century it was assumed that the differentiation potential of adult stem cells is already determined and strictly tissue specific. However, at the same time several laboratories documented, especially in the hematopoietic tis-

Abbreviations used in this paper: CMFDA, chloromethyl-fluorescein-diacetate; HUCB, human umbilical cord blood; N, neurosphere; NP, neural progenitor; NSC, neural stem cell.

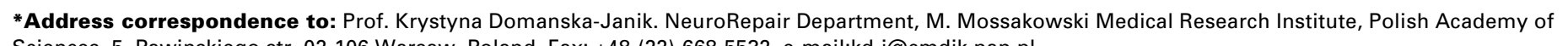
Sciences, 5, Pawinskiego str, 02-106 Warsaw, Poland. Fax: +48-(22)-668-5532. e-mail:kd-j@cmdik.pan.pl 
sues, several meaningful exceptions from this general rule (Eglitis and Mezey, 1997; Ferrari et al., 1998; Woodbury et al., 2000; Lagasse et al., 2000; Sanchez-Ramos et al., 2000; Orlic et al., 2001; Krause etal., 2001; Jiang etal., 2002). In our group we have shown for the first time that mononuclear fraction from human umbilical cord blood (HUCB), containing ontogenetically young but not hematopoietically determined (CD34-negative) stem cells, can acquire features of neural stem cells under defined in vitro conditions (Buzanska et al., 2001; Buzanska et al., 2002), and are able to differentiate in all three types of CNS cell lineages: neurons, astrocytes and oligodendrocytes.

Recent studies have confirmed that adult stem cells extracted in vitro even from other than hematopoietic tissues have also a much broader plasticity of differentiation than originally anticipated (Cao et al., 2003 - for skeletal muscle SC; Wurmser et al., 2004 - for neural SC; Amoh et al., 2005 - for hair follicle SC; Guan et al., 2006 - for testis-derived SC; De Coppi et al., 2007 - for amniotic fluid-derived SC). Another distinct subpopulation of bone marrow cells has been shown to differentiate into various cell lineages (Yoon et al., 2005; Kucia et al., 2006). In addition, such multipotent differentiation of adult stem cells can occur without cell fusion (Harris et al., 2004; Jang et al., 2004; Wurmser et al., 2004) and can contribute to regeneration of different tissues. Discovering embryonic-like potential and differentiation plasticity in several adult stem cell population(s) risen again the question, whether the stem cells (ESC and ASC) have similar very high transcriptional potential for all tissue-specific genes or as in case of adult stem cells the transcriptional potential is limited to certain genes and the transcription is directed by tissue-derived or neighboring cell-specific signals. It is worth to mention here that in the case of inner mass cells (ancestors of ESC) we are dealing with pure population of stem cells which, in the presence of differentiation inhibiting signals in vitro, can be propagated for many cell generations as ES cell lines (Evans and Kaufman, 1981). In contrast, adult SCs appear exclusively in mixed populations of different partially committed cells and there is no proven method (with exception of hematopoietic SC) for their purification

\section{Why we are interested in Human Umbilical Cord Blood (HUCB) - derived cells?}

The beneficial effect of rehabilitation in patients with brain injury was always believed to be based on the augmentation of the two types of inherited endogenous responses: neuroplasticity and neurogenesis (Biernaskie and Corbett, 2001; Komitowa et al. 2005). However, these processes, indicating the existence of endogenous mechanism of repair of damaged nervous tissue, are short lived, probably due to the hostile local environment (Lindvall and Kokaia, 2004).

Hypothesis that neurogenesis is contributing to functional recovery from brain injury focused the research on the development of therapeuthic methods allowing for the enhancement of these naturally occurring mechanisms. One such approach is to introduce, through implantation, an additional pool of exogenous stem cells capable of specific migration, differentiation and integration into the neural circuitries (Kelly et al. 2004; Tabar et al. 2005, for review see Scheffler et al. 2006). Another attractive therapeutic possibility involves enhancement of endogenous neurogenesis through the introduction of growth-factors released by naive or genetically manipulated, infused stem cells.

A variety of cell types have been considered an optimal source for neural cell therapy. In general, transplantable cells should represent a homogenous population available in large quantities, be resistant to cryopreservation, and express low-immunogenicity and genetic stability with appropriate, established differentiation potential. Many investigators favor embryonic stem cells (ES), for the reasons already mentioned above (indefinite expandability and impressive, almost unlimited, differentiation repertoire) (Kelly et al., 2004; Hayashi et al., 2006). However, this source of cells is plagued with severe ethical issues. The other negative side of ES is that proliferation and differentiation are largely uncontrolled, leading to the formation of teratomas (Cao et al., 2000; Fujikawa et al., 2005; Erdo et al., 2003). While there is a significant effort to decipher and control the mechanisms governing the behavior and differentiation of ESC (Baharvand et al., 2007), the results are far from satisfactory, eliminating the possibility of prompt clinical applications of ESC.

A major advantage of the second type of stem cell - derived from fetus or adult tissue-derived progenitors - is that they are usually more defined in terms of organ-specific phenotypical commitment, thus carrying less risk of uncontrolled division. Unfortunately, this source is very limited in quantity and not easy to expand, so has to be considered as having experimental value only.

The third group of non-invasively obtainable stem cells contains cells derived from bone marrow, peripheral blood, cord blood, and, more recently, amniotic fluid (Hermann et al., 2004; Zhao Y et al., 2003,'Buzanska et al., 2002;'De Coppi et al., 2007). A major advantage of these sources is the prospect of auto/ allogenic transplantation with the additional benefit of lack of ethical issues A logistically and economically realistic strategy for such transplantations is to establish a source of standardized, genotypically-defined material available as a cryopreserved, standardized combination of transplant and quasi-pharmaceutical product. HUCB has a good chance of becoming the ideal source for such standardized transplantable material. Our laboratory has successfully derived a non-immortalized cell-line with properties of neural stem cells (Buzanska et al., 2003; Buzanska et al., $2006 b)$. This cell line of HUCB-NSCs serves as a useful prototype for the ideal transplantable material depicted above, and, upon sufficient characterization in animal models, it has a strong potential for clinical use. However the unique properties of HUCBNS cells must be fully understood before any clinical application.

\section{Historical note}

The function of human stem cells in adult central nervous system have been of interest to our group since 1996 - long before the first evidence was provided that human stem cells can be maintained in culture in vitro(Thomsom et al., 1998). The cellular model for this initial research concerning neural stem cells was the cell line derived from human medulloblastoma - named DEV (Dufay et al., 1994). It was characterized by indefinite growth and ability to differentiate into three neuronal cell types, thus showing neural stem cell line character (Derrington et al., 1998). Our special interest focused on transcriptional regulation of glial or neuronal fate decision undertaken by non-differentiated human neural stem-like cells. For that purpose the cells were transfected 
with evolutionary conserved murine or invertebrate genes encoding transcription factors known to be involved in the neuronal or glial differentiation cascade (Buzanska et al., 2001b). Our results obtained in cooperation with the group of Prof. B. Zalc (INSERM) not only confirmed functional conservation of basic HelixLoop-Helix (bHLH) transcriptional factors involved in human neurogenesis, but also pointed out that cellular isolates from human brain tumors contain cells with neural stem potential, which under appropriate conditions, can be multi-directionally differentiated into mature neurons, astrocytes and oligodendrocytes. This is consistent with the recent theory of the cancer stem cells role in oncogenesis and as such it is citied in the relevant literature (Singh etal., Oncogene, 2004).

Evidence for surprising presence of stem cells in the adult human central nervous system together with the proofs for ongoing neurogenesis during adulthood (Eriksson et al., 1998) provoked us to look for the source of nontransformed neural stem cells suitable for further experimental approaches as well as for putative therapy. However, neural stem cells, which are present in adult or developing human brain, are not easily harvestable. What's more, somatic stem cells, unlike embryonic ones, in general have limited life span as they spontaneously differentiate in laboratory culture and thus enter an irreversible growth arrest after a finite number of cell divisions. This phenomenon (except of the latest research data, Conti et al., 2005; De Coppi et al., 2007) was believed as typical for progenitor cells isolated from any fetal or adult human tissue. Thus our challenge was to isolate ethically neutral and non-transformed SC population of neural character, suitable for long-lasting in vitro expansion.

Human umbilical cord blood stem cells (HUCB-SC), in contrast to adult bone marrow stem cells (BM-SC), are less mature and therefore less immunogenic and have a higher proliferation potential associated with extended life span and longer telomeres. We assumed that due to their immaturity and specific postnatal ontogenic position the population of HUCB-SC would retain enhanced capacity to proliferate and expand also in vitro and studies that it may contain a subpopulation of undefined stem cells with flexible phenotype or embryonic-like properties which would allow them to differentiate into neural cell types. The first
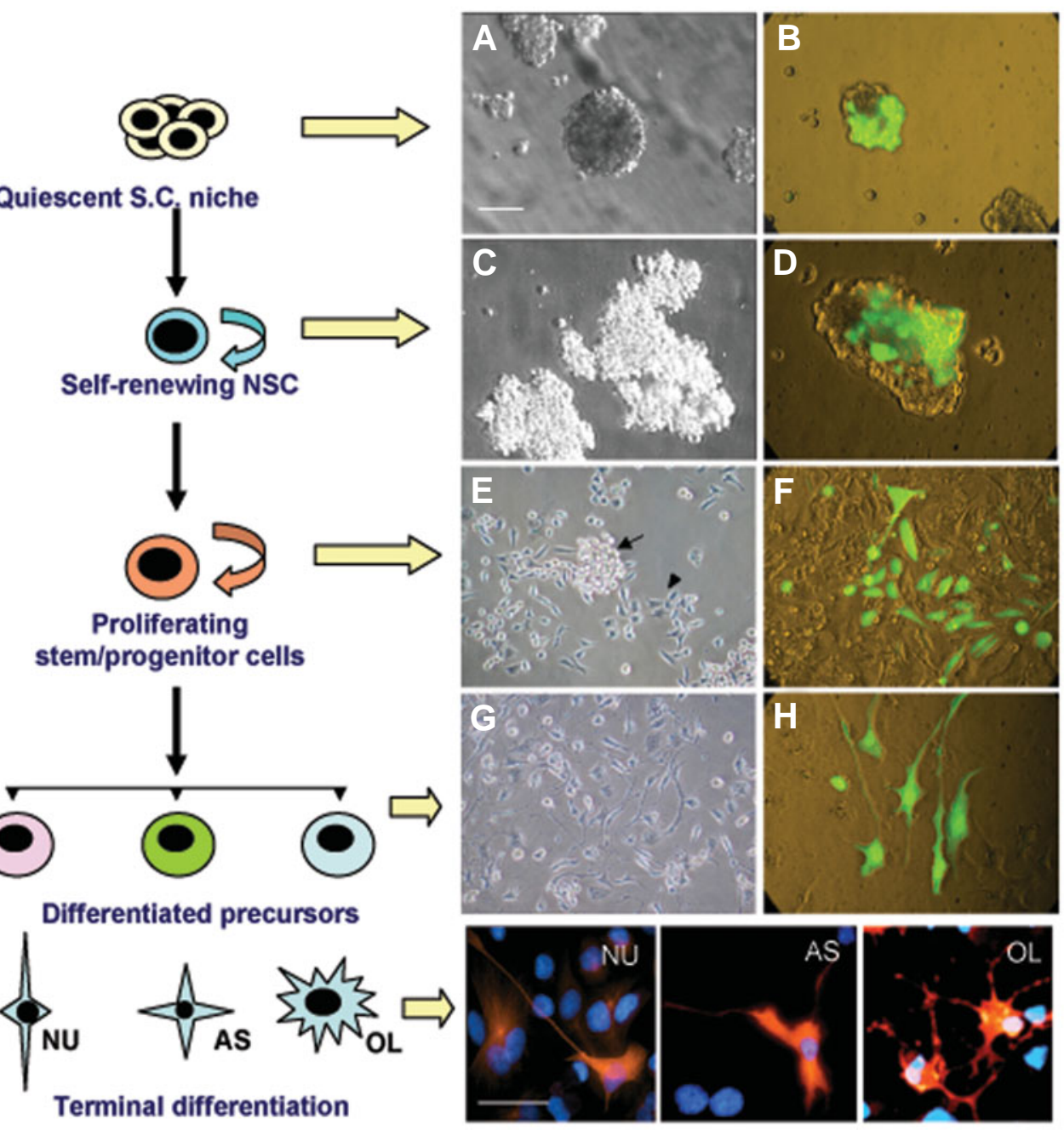

Fig. 1. Developmental steps of human umbilical cord blood-neural stem cells (HUCB-NSC) toward neural lineages. Phase contrast microscopy $(\mathbf{A}-\mathbf{H})$ with additional fluorescence $(\mathbf{B}, \mathbf{D}, \mathbf{F}, \mathbf{H})$ for cultures niche; (C,D) self-renewing, floating HUCB-NSC in defined serum-free medium; (E,F) intermediate, neural committed HUCB-NSC grown in low serum medium at floating (arrow) and adherent (arrowhead) fraction; supplemented with neuromorphogens. Immunocytochemistry: (NU) $\beta$-Tubulin III, (AS) S100 $\beta$, (OL) GalC for neuronal, astrocytic and oligodendrocytic cells respectively. Scale bars, $50 \mu \mathrm{m}$.

positive results confirming these assumptions were obtained in 2001 (Buzanska et al., 2001a) and then published in 2002 (Buzanska et al., 2002). Thereafter, through repeated passages of floating, round-shaped, nestin-positive and clonogenic cells from these neural progenitors population we have established the first, expanding, indefinitely growing HUCB-NSC cell line (Buzanska et al., 2003; Buzanska et al., 2006b).

\section{Neurally-committed cord-blood-derived stem/progeni- tor cells can attain infinitely-self-renewing NSC-like properties}

Phenotypic and functional identity of HUCB-NSC line, their stability, clonogenity, ability to form neurospheres and to differentiate into all neural cell types (Buzanska et al., 2006a; Buzanska 

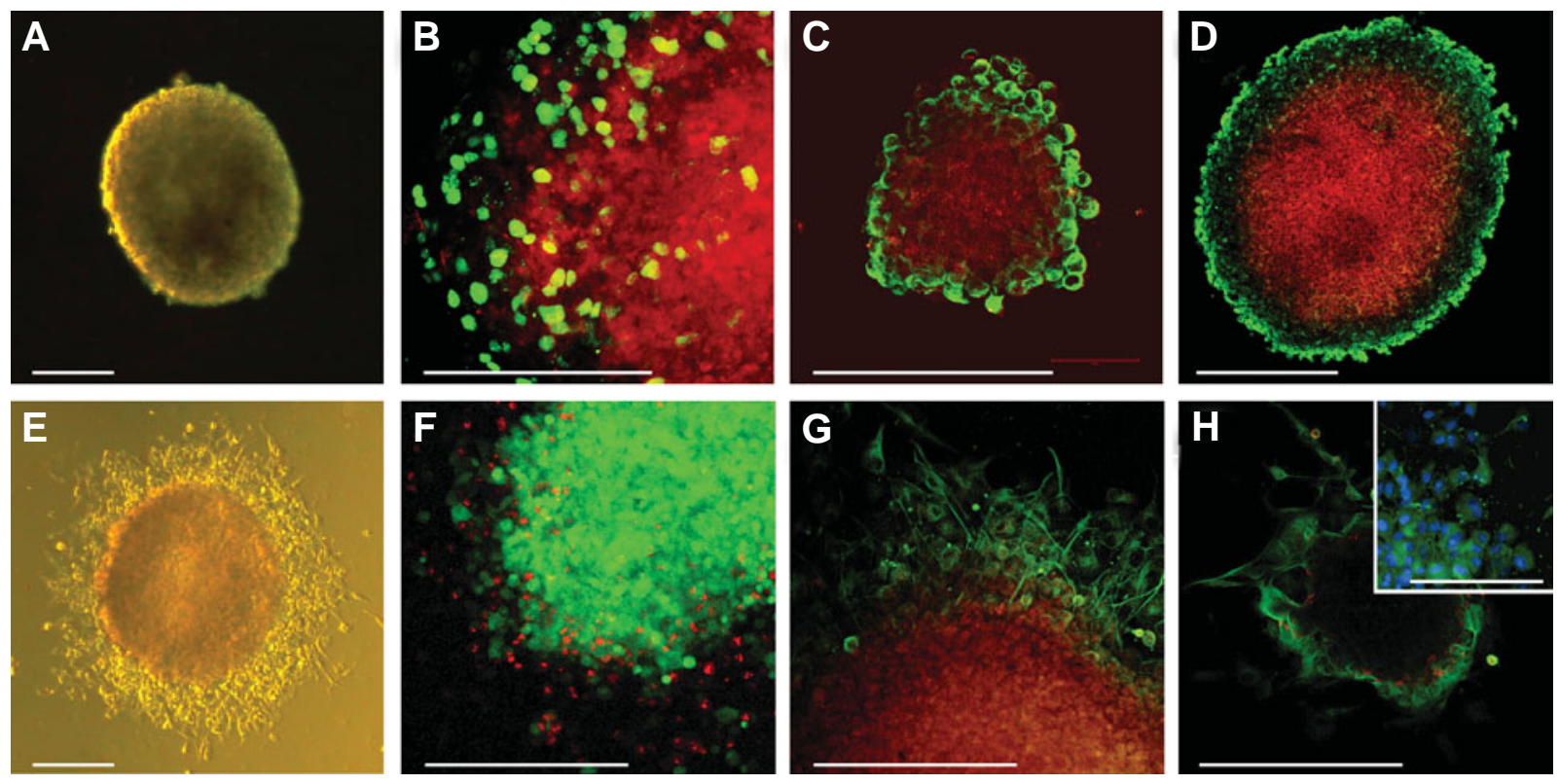

Fig. 2. Immunocytochemical detection of cell markers in neurospheres (N-HUCB) formed from HUCB-NSC. Resting stage of N-HUCB (upper panel); activated stage of N-HUCB (lower panel). (A) Phase contrast microscopy image of floating N-HUCB in serum-free medium; confocal microscopy image of cells expressing: (B) Ki-67 (green) at the surface of N-HUCB; (C) connexin 43 (red) and GFAP (green); (D) nestin (red) and GFAP (green) markers in the different regions of N-HUCB. (E) Phase contrast microscopy image of activated (attached) N-HUCB. Confocal microscopy image of cells expressing: (F) Ki-67 (red) present in migrating from attached neurosphere composed of GFP positive cells; (G) connexin (red) in the centre of N-HUCB and $\beta$-Tubulin III (green) neuroblasts visible at the surface of neuroshere; (H) the majority of cells surrounding activated N-HUCB display $\beta$-Tubulin III (green) and MAP-2 (inset: green). Few cells are GFAP-positive (red), while the cells in the core region of N-HUCB remain negative for these markers. Scale bars, $100 \mu \mathrm{m}$

et al., 2006b) were confirmed in further studies. Critical in vitro analysis involved contrast-phase microscopic observations, gene expression studies using cDNA microarray and quantitative RTPCR followed by immunocytochemical evaluation of the protein expression. Non-transformed character of the HUCB-NSC cell line was proved by the karyotypic analysis and transplantations into immunodeficient non-obese diabetic/severe combined immunodeficient (NOD/SCID) mice. It was shown, that HUCB-NSC grown in continuous culture (for more than 65 passages) displayed normal human karyotype without identifiable chromosomal aberrations in early $\left(9^{\text {th }}-13^{\text {th }}\right)$ and late $\left(22^{\text {nd }}-45^{\text {th }}\right)$ passages. After transplantation into NOD/SCID mice tumor formation was not observed. In addition we did not find enhanced expression of the classical protooncogenes in HUCB-NSCs as compared to the starting population of HUCB mononuclear cells. Stability of the HUCB-NSC cell line was further confirmed by the lack of significant differences in the growth rates, clonogenicity, and differentiation potency between the early and late passages. Single cells isolated from the long-term expanded HUCB-NSC produced clones (cloning efficiency approximately 10\%) of multipotent neural progenitors differentiating into neuronal, astrocytic and oligodendroglial lineages.

Depending upon culture conditions HUCB-NSCs can be maintained at different developmental stages, which reproduce neural stem cell differentiation process (Buzanska etal., 2005), and they can display following phenotypes: 1) non-differentiated "dormant" stem cells residing in neurosphere-like structures (serum-free conditions) (Fig. 1 A, B);2) proliferating, but still non-differentiated neural progenitors in free-floating aggregates (serum-free conditions but under growth factor stimulation) (Fig. 1C, D); 3) prolifer- ating at a high rate cultures of mixed, nondifferentiated (floating) and already committed (adherent cells) neural progenitors when grown in low serum (2\%) conditions (Fig. $1 \mathrm{E}, \mathrm{F}$ ); 4) the adherent cells differentiating into neuronal, astrocytic and oligodendroglial lineages when cultured in high serum or low serum media supplemented with neuromorphogens (Fig.1 G, H).

HUCB-NSC line can be easily halted and harvested at these different stages of neural commitment, thus provides a suitable model for the study of the mechanisms governing neural stem cells developmental fate decisions. Such system can be experimentally manipulated in vitro by the presence of trophic factors, mitogenes, neuromorphogenes and transduced genes. These cells can be also used for large-scale screening of compounds for their neurotoxic effect or for new drug discovery. Currently HUCBNSC line is under implementation for developmental neurotoxicity testing in collaborative effort with ECVAM/JRC.

The ability of HUCB-NSCs to form neurospheres, a hallmark of genuine neural stem cells, further confirmed stem character and neural commitment of cord blood-derived line. Neurosphere, a well characterized, multicellular structure (Doetsch et al., 2003) is assumed to follow typical NSC behavior in the CNS-specific niches. Nonadherent HUCB-NSC spheres (Jurga and DomanskaJanik, 2004) are linage negative for advanced neuronal, astroglial or oligodendroglial markers, but contain cells expressing markers of uncommitted human neural stem cells, like Nestin and GFAP (Fig. 2). Upon attachment, in the presence of serum, surface cells of neurosphere start to migrate away from the center then differentiate into neurons ( $\beta$-tubulin III - red), astrocytes (GFAP green) and oligodendrocytes (data not shown). These results are consistent with the pattern of differentiation in neurospheres 
derived from the human CNS (Caldwell et al., 2001) or human embryonic stem cells (Benzing et al., 2006).

Neural character of HUCB-NSC line was further evaluated by comparative analysis of the transcriptional profile (Affymetrix DNA microarray probes HG-U133, covering the expression of about 40.000 genes), between the free-floating, non-differentiated HUCB-NSC and its starting, nonselected cell population mononuclear cell (MNC) fraction of human cord blood. It was shown that more than $90 \%$ of stem and neural related genes are up-regulated in HUCB-NSC as compared to its reference population of MNC. "Stemness" up-regulated in HUCB-NSC genes encode proteins involved in Wnt, Lif and Notch signaling pathways, that are known to regulate stem cell self-renewal and proliferation (Sato et al., 2004; Melton and Cowan, 2004). They are represented mainly by frizzled, wingless, Lif and notch gene families (Fzd8, Fzd7, Wnt5a, Ctnmb1, Lif, LifR, Erbb2, Jak3, Notch2, Notch3, Notch4, Jag2, DI/3, Hey1, Pnn1 and 2, Adam15, $17,23)$. In addition to activation of pro-neural genes like: NeuroD1, Otx1, and Msi, studies reveled expression of Oct4, Sox2, Mdr1, Rex1 - the genes characteristic for pluripotent embryonic stem cells. Thus HUCB-NSC can retain their potential pluripotency, while executing exclusively neural-restricted gene expression (Jurga et al., 2006b).

Of special interest was the high activity of FGF signaling pathway in HUCB-NSC. Up-regulation of FgfR 1 was shown to be a hallmark for neural commitment of clonally related stem cells (Hsieh and Gage, 2004). In non-differentiated HUCB-NSC expression of $F g f R 1$ gene was increased up to 600 -fold. Since FGF signaling pathway was also shown to be involved in epigenetic control of self renewal activity of stem cells (Hsieh and Gage, 2004; Rao, 2004), significantly increased expression of FgfR1 may be important not only for neural commitment, but also for the self-renewal capacity of HUCB-NSC. Microarray data and the parallel study by quantitative RT-PCR revealed activation in HUCB-NSCs of several pro-neural genes (Sox2, NeuroD1, Otx1, and Msi1), but also the lack of expression genes typical for mesodermal (T gene) and endodermal differentiation (Foxa 1) (Jurga et al., 2006b; Buzanska et al., 2006a), further indicating neural commitment of the cell line.

Nestin-positive HUCBNSC may undergo spontaneous differentiation into cells expressing markers typical for all main neural-type cells, but extend of this differentiation highly depends upon plating density, attachment conditions and presence of serum in the medium. In standardized conditions: on poly-Ilysine coated surface and in low serum medium (2\%)
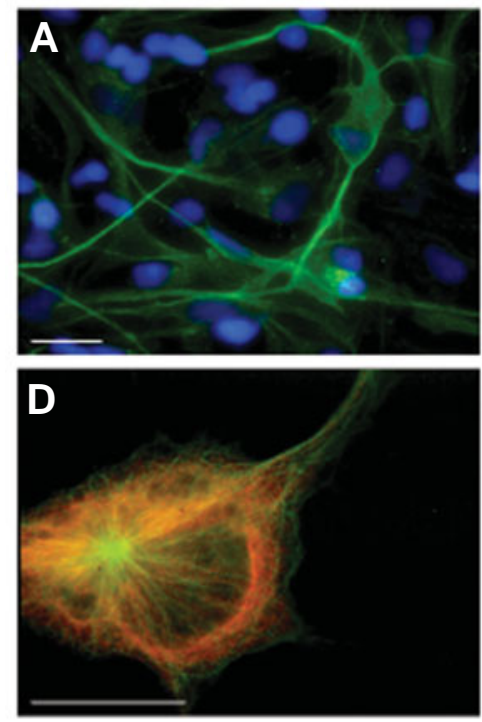
$50 \mu \mathrm{m} ;(D, E, F) 20 \mu \mathrm{m}$.
HUCB-NSC cells cultured for two weeks expressed neuronal ( $\beta$ tubulin III), astrocytic (S-100 $)$ and oligodendroglial markers up to $28 \%, 10 \%$ and $1 \%$ of total cell number, respectively (Buzanska et al., 2005). Application of neuromorphogenes (RA, BDNF and diButyryl cyclic AMP (dBcAMP)) to HUCB-NSC or co-culture in conditions reassembling natural niche: with rat cortical brain cells or on hippocampal slices (Fig. 3), induced further differentiation and expression of more advanced neuronal markers like NF-200 or MAP-2 (Jurga et al., 2006b; Buzanska et al., 2006a). We have also shown, that lineage specific, directed differentiation of HUCBNSC is also possible. Different combinations of several growth factors and neuromorphogens, such as PDGF-AA, PDGF-BB, Ciliary Neurotrophic Factor (CNTF), GDNF, T3 and dBcAMP, applied to standardized, plating and culture conditions ( $2 \%$ serum, no mitogens, for 2 weeks in culture), allowed us to establish controlled conditions for the directed commitment into neuronal, astrocytic and oligodendroglial lineages (unpublished).

Nevertheless, nearly exclusive (more than $80 \%$ ) commitment into neuronal phenotype was achieved upon prolonged ( 2 to 4 weeks) differentiation in the presence of dBcAMP. The gene expression profile of HUCB-NSCs changed substantially in these conditions. Activated genes (as compared to non-differentiated HUCB-NSCs) were mainly related to the signaling pathways, neurotransmitters, receptors, or channels involved in neuronal functions (Buzanska et al., 2006a; Buzanska et al., 2006b; Sun et al., 2005). Up-regulation of genes was followed by the expression of corresponding proteins, which included: GluR2, dopamine, serotonin and acetylcholine receptors, Gad 65, GABARAPL1 and 3; TAU, SV2, TH and many more involved in synaptic transmission and function of gabaergic, glutamatergic and serotoninergic neurons (Fig. 3).

Mechanisms underlying neuronal differentiation of HUCB-
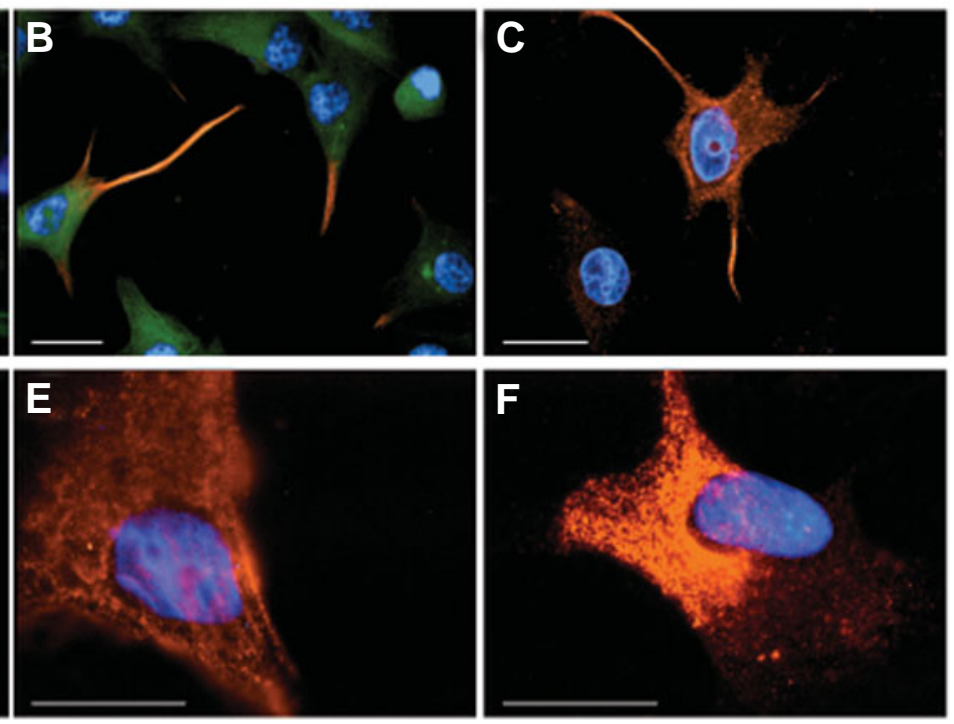

Fig. 3. Immunocytochemical detection of neuronal markers in dBcAMP-differentiated HUCB-NSC. (A) Expression of $\beta$-Tubulin III (green); (B) merger of $\beta$-Tubulin III (green) and microtubule associated protein 2 (MAP2, red) immunostaining. Note that MAP2 is localized to neuronal extensions. (C) Expression of GABA receptor 1associated protein (GABAR1AP, red); (D) $\beta$-Tubulin III (green) and neurofilament 200 (NF200, red) co-expression. Note filamentous organization of immunostained proteins; (E) glutamate receptor 2 (GluR2, red) and (F) dopamine receptor 2a (DR2a, red) immunodetection. Cell nuclei were stained blue with Hoechst 33258. Scale bars, $(A, B, C)$ 

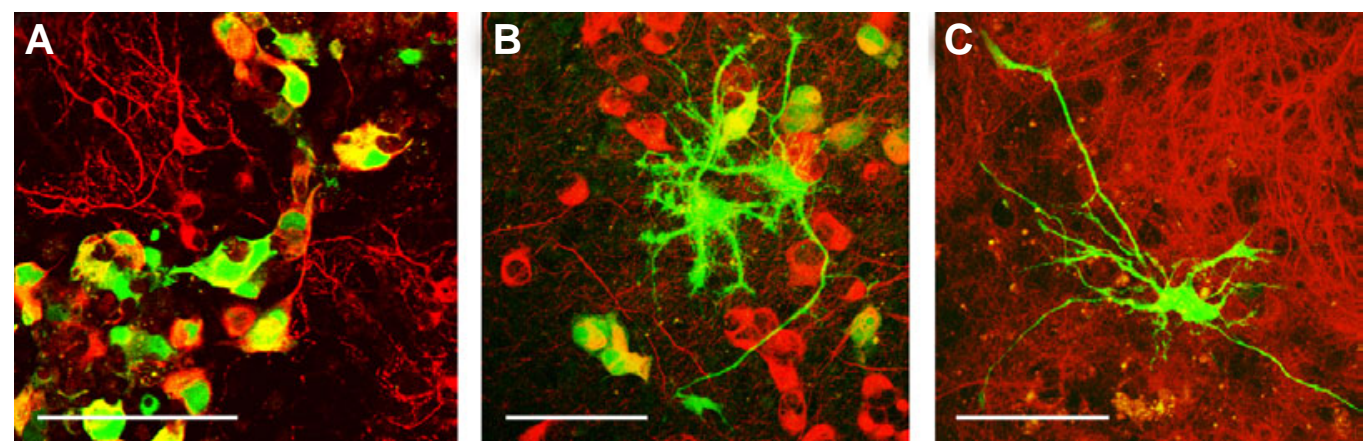

Fig. 4. Confocal microscopy image of HUCB-NSC transplanted onto rat hippocampal organotypic slices and cultured for 2 weeks. $H U C B-N S C$ expressing: (A) GFP (green) and $\beta$ Tubulin III (red); (B) GFP (green) and NF-200 (red); (C) GFP (green) and TUJ1 (red) are seen on the slices with coexpression of these markers (yellow). Scale bars, $100 \mu \mathrm{m}$.
NSC are thought to resemble the mechanisms operating in developing mammalian brain, thus involve bHLH cascade of transcriptional regulation. In gain-of function experiments we have shown that ID1 (endogenous inhibitor of bHLH transcriptional factors) inhibits neurogenesis. Negative regulation of HUCBNSC neuronal differentiation is coupled with translocation of ID1 protein from cytoplasm to the nucleus suggesting its possible usage as a stage-specific marker of neurogenesis (Jurga et al., 2006a).

However, assuming that HUCB-NSC line may be a source of cells for possible therapeutic application or reliable model for in vitro tests of terminal, neuronal differentiation, we needed to provide the strong physiological evidence for its functional differentiation. For such purpose HUCB-NSC must not only develop morphological characteristics of neurons, but also voltage- and ligand- gated ion channels, that would allow them to function within a neural network and respond to neurotransmitters released from neighboring neurons. The whole-cell patch clamp technique for recording electrophysiological properties of HUCBNSCs was applied to address this issue (Sun et al., 2005). Two types of voltage-sensitive currents: (1) inward rectifying current (Kir) and (2) outward rectifying potassium current (IK+) together with several ligand-gated currents typical for neuronal cells, were recorded from differentiated HUCB-NSC. All this currents could be blocked by specific antagonists and restored after their removal.

Further functional evidence is provided by the ability of HUCBNSC to grow and terminally differentiate directly on silicon or glass multi-electrode neurosensor (Bionas Neurosensorix Measurement System, Rostock and Central Network for Neurons, Texas respectively). Chip-cultured HUCB-NSCs formed a neuronal-like network capable to generate spontaneous field potential activity (unpublished data). These results show that HUCB-NSC could conceivably be differentiated in spontaneously firing, functional neuron-like cells.

\section{Possible mechanisms of transition of cord blood mono- nuclear cells toward neural phenotypes}

It is still not clear whether exposure to specific factors in vitro makes HUCB cells disregard their hematopoietic identity due to epigenetic reprogramming in the mechanism called trans- or dedifferentiation (Abkowitz, 2002; Jiang et al., 2002; Korbling et al., 2002; Poulsom et al., 2002; Terskikh et al., 2001), or whether they acquire new features by directed expansion of a preexisting, embryonic-like, pluripotent stem cell subpopulation positively selected during employed experimental procedures (McGuckin et al., 2004; Habich et al., 2006).

According to our recent data (Habich et al., 2006) freshlyisolated HUCB mononuclear fraction does not express or has very low level of expression of gene or protein markers characteristic for lineage-specific progenitors. Instead, genes believed to be master regulators of the pluripotent stem state, i.e. Oct3/4, Sox2, Mdr1 and Rex1, have been found to be expressed in the native, hematopoietic progenitors-depleted (CD34-) cord blood isolates. During $24-48 \mathrm{hr}$ cell culture in strictly specified conditions, the frequency of Nestin and CD133 immunopositive cells (lineage-specific NSC markers) increased rapidly in parallel with cell proliferation rate (Ki67 labeling), and a near 10-fold increase of the "side population" (as measured by high Hoechst 33342 efflux, an approved test for the presence of stem/progenitor cells). Concomitantly, cultured cells start to form aggregates and successively express other pro-neural genes, i.e. enhanced Sox2, OTX1, Nestin, GFAP and NF-200. During the next few days immunoreaction for the wide panel of neural markers: $\beta$-tubulin III, MAP2, GFAP, S100 $\beta$, Doublecortin, NG2 and GalC, increased in the majority of cultured cells with reciprocal lowering of all of the "stemness" markers. At this stage, cells adhere to the bottom, disperse to form a monolayer and decrease their proliferation rate (Ki67 expression). Additional treatments with neuromorphogenes or co-culturing with rat-brain primary culture induced further differentiation of these early neural precursors toward more advanced neuronal phenotypes. However, gradual depletion of Oct3/4, Rex-1, Sox2 and Ki67 clearly indicates the onset of predominance of non-dividing, differentiated cells over the uncommitted, self-renewing and proliferating stem/progenitors (HUCB-NS/P), leading to their successive depletion and dilution in vitro and finally to senescent of the culture.

However, repeated passages of floating, nestin-positive, roundshaped cells appearing occasionally in the supernatant of these primary monolayer cultures treated with Epithelial Growth Factor (EGF) or EGF/FGF, allowed us to prolong culture expansion and, for the first time, to establish described above non-immortalized human umbilical cord blood neural stem cell line (HUCB-NSC) (Buzanska et al., 2003; Buzanska et al., 2006b). The exact mechanisms responsible for such substantial change in HUCB cells behavior in vitro are unknown at present. The asymmetric type of the progenitor proliferation kinetics leading to culture senescence (Sherley, 2002) is assumed as typical for all stem cells residing in the specialized niches of adult organism whereas the symmetric balance between maintenance of undifferentiated stem cells and lineage committed progeny would provide a force 
to enormous tissue expansion observed mainly during development. Thus, symmetric type of cell expansion kinetic, responsible for indefinite growth in vitro has been attributed to embryonic SC whereas asymmetric division is treated as evolutionary conserved feature of somatic stem cells involved in space- and timelimited organogenesis and tissue maintenance. Until now, all nontransformed stem cell lines developed from non-embryonic tissues such as CB-derived (Kogler et al., 2004; Xiao et al., 2005), amniotic fluid AFC (De Coppi et al., 2007) and our HUCB-NSC line (Buzanska et al., 2006b) contain the cells expressing stage specific embryonic markers (Oct3/4, Seea-4, Rex1, Mdr1, ect.), that may suggest maintenance of the stem cell population with the ability to perform embryonic-like, symmetric type of stem cell division.

These primitive, pluripotent stem cells in vitro are particularly sensitive to environmental influence provided by direct contacts with other cell types or tissue-specific instructive signals, among them these promoting "spontaneous" differentiation. Thus, effective inhibition of cell differentiation signals and promotion of symmetric type of stem cell division would be primary requirement for long-lasting culture expansion (Sherley, 2002). The precise definition of these events and establishment of standard procedure for prolonged HUCB-NSC expansion in vitrois the main goal of our study.

\section{The cord blood challenge for brain repair}

Cord blood cells have been a part of clinical practice for over 15 years and offer several advantages in terms of clinical transplantation (Broxmeyer etal., 1989; Gluckman etal., 1989; Laughlin et al., 2001). Apart from hematological disorders CNS diseases represent especially daunting challenges for cell-based strategies of repair. Studies by a number of groups support the idea that infusion of cells obtained from human cord blood lessen neural damage resulting from stroke, neurodegenerative diseases and spinal cord injury (Nan et al., 2005; Ende et al., 2000; Chen et al., 2006).

Cord blood has been shown to contain hematopoietic stem cells, mesenchymal stem cells and endothelial precursor cells. At the present time it is not known whether any of these stem cells can ameliorate deficits seen in neurologically compromised animals treated with cord blood but it is possible that a combination of all these cells may contribute to observed functional restitution. The results from our study addressed this problem and demonstrated that intra-carotid artery infusion of human umbilical cord blood cells depleted of hematopoietic precursors and directed in vitrotoward neural phenotype (NP) (Habich et al., 2006), ameliorate neurological deficits associated with stroke-like, ouabaininduced brain injury. Rats transplanted with HUCB-NP showed significant behavioral improvement in walking beam and rotarod performance after one week, with further progress in recovery of locomotor's deficits observed after 4 weeks (Janowski et al., 2004; Gornicka et al., 2005; Gornicka et al., 2006). Functional therapeutic benefit was correlated with obvious reduction in lesion volume in transplanted rats in comparison to control, nontransplanted counterparts. Our results are consistent with other experiments which, in contrast to ours, have utilized non-selected cord blood to treat CNS injury. In all these reports HUCB cell administrated intravenously or intraperitonealy modified posi- tively the severity of neurological deficits caused by middle cerebral artery occlusion (MCAO) (Willing et al., 2003; Vendrame et al., 2004; Xiao et al., 2005; Newcomb et al., 2006; Meier et al., 2006). Also intravenous administration of umbilical cord blood improved functional state of the brain and behavioral deficits in rats suffering from hemorrhagic or traumatic brain and spinal cord injury (Nan et al., 2005; Lu et al., 2002; Ereniev et al., 2005; Saporta et al., 2003). All these data suggest that cells with neural progenitor properties are contributing substantially to all these CB therapeutic effects.

Furthermore, therapeutic benefits of $C B$ infusion have been reported in chronic neurodegenerative diseases. It has been shown that infusion of HUCB cells delayed the progression of amyotrophic lateral sclerosis (ALS) and increased lifespan of the diseased, transgenic mice (Ende et al., 2000; Garbuzova-Davies et al., 2003). Systemic delivery of HUCB cells has an ability to prevent circulatory shock and resulting brain damage in the heatstroke animal model (Chen et al., 2006). Transplantation of umbilical cord blood in babies with infantile Krabbe's disease that favorably altered their natural history could be the first, promising example from human clinic. Infants who underwent HUCB cell graft before the development of symptoms showed progressively increasing central myelination and continued gains in developmental skills and cognitive function (Escolar et al., 2005; Escolar et al., 2007). These therapeutic benefits of cord blood infusion may hold hope for slowing the progression of other chronic neural diseases.

Beside of all these promising data it is still not clear how transplanted stem cells can participate in the CNS repair process. Besides our studies there are many reports from other laboratories of cord blood cells turning into brain cells i.e. neurons, astrocytes, oligodendrocytes, endothelial cells and microglia both in vitro and in vivo (Buzanska et al., 2006; Borlongan and Hess, 2006; English etal., 2006; Zandonella, 2005; Tagushi et al., 2004; Asheuer et al., 2004). Thus, the most straightforward idea is that cord blood stem cells infused systemically reach brain, differentiate into mature cell types and simply replace the lost cells. However, until now this mechanistic view cannot reconcile the experimental findings. In our studies only a few transplanted HUCB-NP cells were detected in the ipsilateral hemisphere of ischemic brain of injured rats (unpublished). This is consistent with majority of other studies where only low number of human cells was detected in the injured tissue of grafted rats (Vendrame et al., 2004; Nan et al., 2005; Nystedt et al., 2006). The limitation of the presence of HUCB cells after systemic transplantation might be the effect of their rejection in discordant xenogeneic recipients. It is well known that immunosuppressive treatment is a key determinant of grafted cells survival in a manner of xenograft paradigms (Brevig et al., 2000; Vendrame et al., 2004). Thus, a majority of experimental xenografting protocols included the use of high doses of cyclosporin A. However, although this classical immunosuppressant can effectively inhibits $T$ cell activity it is inadequate at protecting xenografts from direct immune attack that involves the innate responses of the recipients such as complement system, natural antibodies, the coagulation cascade and natural killer cells (Cascalho and Platt, 2001).

The next concern is related to brain accessibility for systemically transplanted cells. We have detected intra-arterially infused cells only at the border of lesion at $24 \mathrm{~h}$ after delivery (Janowski 
et al., 2004). Borlongan et al. (2004) have shown that HUCB cells do not enter the brain parenchyma even when co-infused with blood-brain barrier permeabilizer. Apart of these confusing results numerous studies steadily revealed that HUCB graft can reduce cerebral infarct volume and improve behavioral recovery. Therefore, rapid improvement within few days as seen in HUCB transplanted animal models may indicate that mechanisms other than cell replacement are of primary importance in all these cases. It has been suggested that transplanted HUCB stem cells may repair brain damage acting as bystander regulators of neuron and glia rescue via the release of neurotrophic factors. Human umbilical cord blood cells as well as their neural derivatives produce different neurotrophic factors i.e. brain-derived neurotrophic factor (BDNF), glial derived neurotrophic factor (GDNF), nerve growth factor (NGF), neurotrophin 3 (NT3) and neurotrophin 4-5 (NT4-5) (Fan et al., 2005). The results of Borlongan et al. (2004) demonstrated that intravenous HUCB infusion significantly increase GDNF, BDNF and NGF brain levels in stroke animals as compared with nontransplanted counterparts. It is also possible that in addition to the role of already known or unknown factors secreted by transplanted cord the blood cells themselves are responsible for functional improvement following CNS lesion.
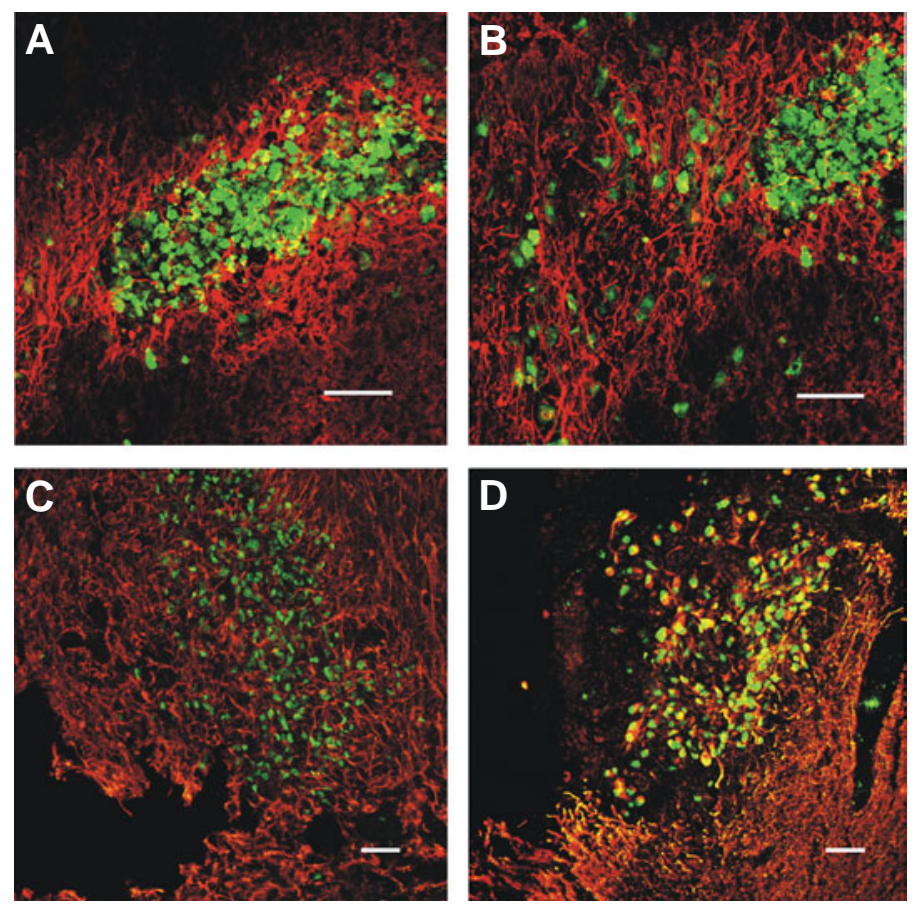

Fig. 5. Immunohistochemical staining of HUCB-NSCs transplanted into lesioned rat brain. (A) 3 days after transplantation of CMFDAlabeled donor cells (green) in transplantation side. Co-staining of these cells with neuron specific anti-NF-200 antibody (yellow) can be found in a minimal number of cells. (B) Migrating CMFDA-labeled HUCB-NSCs (green) surrounding NF-200 reactive host neuron (red) 3 days after cells injection. (C) 7 days after transplantation, HUCB-NSCs stained with the human nuclei marker NUMA (green) were seen in close vicinity of GFAP reactive astrocytes (red). (D) 7 days after transplantation, HUCB-NSCs stained with human nuclei marker NuMA (green) co-expressed the neuronal marker NF-200 (red cytoplasm and protrusions) in the infarct area. Scale bar, $50 \mu \mathrm{m}$.
Another mode of delivery of stem cells, proposed in various experimental and clinical settings, is their direct brain implantation. In our own studies of the methods of selection of HUCBNSCs we have tested behavior of these cells after intraparenchymal brain grafting. We showed that shortly after transplantation into intact brain of adult rats the cells migrate from the injection site and then disperse through the host brain tissue during the first few days. However, their survival is seriously compromised by local inflammation and then acute rejection (Janowski et al., 2006a; Janowski et al., 2006b). Our results are in agreement with studies from other laboratories where relatively low cell survival was noticed after intraparenchymal xenograft despite of the usage of classical Cyclosporin A (CsA)-induced immunosuppression of the host immune response (Walczak et al., 2004; Kogler et al., 2004; Pan et al., 2005). To explain this rapid adverse reaction Newman et al. (2006) have shown that HUCB cells produced a variety of cytokines i.e. IL-8, IL-1 $\alpha$ and chemokines i.e. MCP-1. These factors, being chemoattractants for the cells mobilized as a first line defense system after xenotransplantation, must be considered as one of the critical factors. The previously held view that the brain was an absolute immunologically neutral site allowing indefinite survival without rejection of cell grafts has proven to be wrong. Thus, the brain should be regarded rather as a site where immune responses occur albeit in a tissue-specific, modified form, which directly limits graft survival.

To shed a light on this problem we have studied HUCB-NSCs behavior after their transplantation into organotypic rat hippocampal cultures, the model where immunological host reactions are lacking (Jurga et al., 2006b). In this condition we have observed advanced phenotypic differentiation of the transplanted cells mainly toward neuronal lineage. Transplanted cells seemed to integrate well with the rat neuronal network elaborating extensive cell-cell contacts with surrounding rat hippocampal tissue (Fig. 4).

Also neonatal rats with incompletely developed immunological system provide more permissive model to intracranial HUCB cells transplantation (Zigova et al., 2000; Zigova et al., 2002). In our experiments we have shown that HUCB-NSC transplanted into subventricular zone of neonatal 1-day old rats survive significantly better than in adults, migrate along the rostral migratory pathway and express lineage-specific markers (TUJ-1, NF-200, GFAP, S-100ß) (Kozlowska et al., 2005).

Surprisingly, CNS injury, when compared with intact tissue, apparently improved viability of transplanted stem cells and directed their migration toward injured area. In our ouabain model of brain injury there is a high activation of macrophage/microglia and astrocytes, induced by the infarct itself (Kozlowska et al., 2006). It seems plausible to postulate that dynamic interplay between various cytokines and trophic factors released by injured tissue, inflammatory cells and factors provided by grafted HUCBNSCs, may create favorable microenvironment for longer cell survival. Indeed, the substantial number of transplanted HUCBNSC cells migrated and accumulated around the injured area (Fig.5). Seven days after transplantation high number of these cells exhibited neuronal phenotypes (NF-200) and, to lower extend, glial (GFAP, S-100 $\beta$ ) cell markers. Some of these cells survived for 4 weeks; however most of them disappeared during this time, despite of employed CsA immunosuppression (Kozlowska et al., 2007). These results agree with other reports where only a few transplanted HUCB cells were found in injured 
CNS at 4-6 weeks after transplantation (Liu etal., 2006; Kuh et al., 2005). Thus, it seems evident that HUCB cells grafted to the brain of adult rats are the subject of considerable immune surveillance. The transplantation of any type of alien cells invariably initiates mechanisms that coordinate innate and adaptive immune responses. As a consequence the majority of HUCB cells transplanted to the adult brain of rodents exhibit poor long-term survival and meager differentiation.

The past two decades have shown significant progress in basic understanding of adult stem cells biology. HUCB-derived and neurally committed cells, due to their capacity for self renewal, multilineage differentiation, plasticity and ability for long-lasting culturing in vitro, make them unique as a powerful tool for the cell therapy of a wide spectrum of neurological diseases. However, in spite of the first promising data it would be much premature at this step of our knowledge to launch any relevant clinical trials. Instead, there is an urgent need for deepening of our understanding of adult stem cell biology and to improve available animal models to induce tolerance toward alien human cells. This would be critical for exploring the real power of human stem cells in any preclinical experimental settings. In addition, the immunology of grafted neural stem/progenitor cells of hematopoietic-tissue origin has not been extensively studied. Overall, only after solving all these problems we would be able to determine whether, to what extend, and by which mechanism(s), the transplantation of defined CB-derived neural progenitor/stem cell populations can be used to cure human brain.

\section{Acknowledgements \\ This work was supported by Polish Ministry of Scientific Research and Higher Education grants: 2P05A17729 and 2P05A5430.}

\section{References}

ABKOWITZ, J.L. (2002). Can human hematopoietic stem cells become skin, gut, or liver cells? N. Eng/ J. Med. 346(10): 770-772.

AMOH, Y., LI, L., CAMPILLO, R., KAWAHARA, K., KATSUOKA, K., PENMAN, S. and HOFFMAN, R.M. (2005). Implanted hair follicle stem cells form Schwann cells that support repair of severed peripheral nerves. Proc. Natl. Acad. Sci. USA 102(49): 17734-17738.

ANSEL, K.M., LEE, D.U. and RAO, A. (2003). An epigenetic view of helper T cell differentiation. Nat. Immunol. 4(7): 616-623.

ASHEUER, M., PFLUMIO, F., BENHAMIDA, S., DUBART-KUPPERSCHMITT, A., FOUQUET, F., IMAI, Y., AUBOURG, P. and CARTIER, N. (2004). Human CD34+ cells differentiate into microglia and express recombinant therapeutic protein. Proc. Natl. Acad. Sci. USA 101(10): 3557-3562.

BAHARVAND, H., MEHRJARDI,N.Z., HATAMI, M., KIANI, S., RAO, M. and HAGHIGHI, M.. (2007). Neural differentiation from human embryonic stem cells in a defined adherent culture condition. Int. J. Dev. Biol. 51: 371-378.

BENZING, C., SEGSCHNEIDER, M., LEINHAAS, A., ITSKOVITZ-ELDOR, J. and BRUSTLE, O. (2006). Neural conversion of human embryonic stem cell colonies in the presence of fibroblast growth factor-2. Neuroreport 17(16): 16751681

BIERNASKIE, J. and CORBETT, D. (2001). Enriched rehabilitative training promotes improved forelimb motor function and enhanced dendritic growth after focal ischemic injury. J. Neurosci. 21(14): 5272-5280.

BORLONGAN, C.V., HADMAN, M., SANBERG, C.D. and SANBERG, P.R. (2004). Central nervous system entry of peripherally injected umbilical cord blood cells is not required for neuroprotection in stroke. Stroke 35(10): 2385-2389.

BORLONGAN, C. and HESS, D.C. (2006). New hope for stroke patients: mobilization of endogenous stem cells. CMAJ174(7): 954-955.

BREVIG, T., HOLGERSSON, J. and WIDNER, H. (2000). Xenotransplantation for
CNS repair: immunological barriers and strategies to overcome them. Trends Neurosci. 23(8): 337-344.

BROXMEYER, H.E., DOUGLAS, G.W., HANGOC, G., COOPER, S., BARD, J., ENGLISH, D., ARNY, M., THOMAS, L. and BOYSE, E.A. (1989). Human umbilical cord blood as a potential source of transplantable hematopoietic stem/ progenitor cells. Proc. Natl. Acad. Sci. USA 86(10): 3828-3832.

BUZANSKA, L., MACHAJ, E.K., ZABLOCKA, B., POJDA, Z., BERDOWSKA, P. and DOMANSKA-JANIK, K. (2001a). Human cord blood derived neurons, astrocytes and oligodendrocytes. J. Neurochem. 78 Supplement 1, 58.

BUZANSKA, L., SPASSKY, N., BELIN, M.F., GIANGRANDE, A., GUILLEMOT, F., KLAMBT, C., LABOUESSE, M., THOMAS, J. L., DOMANSKA-JANIK, K. and ZALC, B. (2001b). The human medulloblastoma cell line DEV is a potent tool to screen for factors influencing differentiation of neural stem cells. J. Neurosci. Res. 65: 17-23.

BUZANSKA, L., MACHAJ, E.K., ZABLOCKA, B., POJDA, Z. and DOMANSKAJANIK, K. (2002). Human cord blood-derived cells attain neuronal and glial features in vitro. J. Cell Sci. 115: 2131-2138.

BUZANSKA, L., STACHOWIAK, E., STACHOWIAK, M.K. and DOMANSKA-JANIK, K. (2003). Neural stem cell line derived from human umbilical cord bloodmorphological and functional properties. J. Neurochem. 85 Supplement 2, 33.

BUZANSKA, L., HABICH, A., JURGA, M., SYPECKA, J. and DOMANSKA-JANIK, K. (2005). Human cord blood - derived neural stem cell line - possible implementation in studying neurotoxicity. Toxicol In Vitro 19: 991-999.

BUZANSKA, L., JURGA, M. and DOMANSKA-JANIK, K. (2006a). Neuronal differentiation of human umbilical cord blood neural stem-like cell line. Neurodegener Dis. 3(1-2): 19-26.

BUZANSKA, L., JURGA, M., STACHOWIAK, E.K., STACHOWIAK, M.K. and DOMANSKA-JANIK, K. (2006b) Neural stem-like cell line derived from a nonhematopoietic population of human umbilical cord blood. Stem Cells Dev. 15(3): 391-406.

CALDWELL, M.A., HE, X. and WILKIE, N. (2001). Growth factors regulate the survival and fate of cells derived from human neurospheres. Nature Biotechno/ogy 19: 475-479.

CAO, B., ZHENG, B., JANKOWSKI, R.J., KIMURA, S., IKEZAWA, M., DEASY, B. CUMMINS, J., EPPERLY, M., QU-PETERSEN, Z. and HUARD, J. (2003) Muscle stem cells differentiate into haematopoietic lineages but retain myogenic potential. Nat. Cel/ Biol. 5(7): 640-646.

CAO, F., LIN, S., XIE, X., RAY, P., PATEL, M., ZHANG, X., DRUKKER, M., DYLLA, S.J., CONNOLLY, A.J., CHEN, X., WEISSMAN, I.L., GAMBHIR, S.S. and WU, J.C. (2006). In vivo visualization of embryonic stem cell survival, proliferation, and migration after cardiac delivery. Circulation 113(7): 1005-1014.

CASCALHO, M. and PLATT, J.L. (2001). The immunological barrier to xenotransplantation. Immunity 14(4): 437-446.

CHEN, S.H., CHANG, F.M., TSAI, Y.C., HUANG, K.F., LIN, C.L. and LIN, M.T (2006). Infusion of human umbilical cord blood cells protect against cerebral ischemia and damage during heatstroke in the rat. Exp. Neurol. 199(1): 67-76.

CONTI, L., POLLARD, S.M., GORBA, T., REITANO, E., TOSELLI, M., BIELLA, G. SUN, Y., SANZONE, S., YING, Q.L., CATTANEO, E. and SMITH, A. (2005). Niche-independent symmetrical self-renewal of mammalian tissue stem cell. PLOS Biology 3(9): 1594-1606.

DE COPPI, P., BARTSCH, G.JR., SIDDIQUI, M.M., XU, T., SANTOS, C.C., PERIN L., MOSTOSLAVSKY, G., SERRE, A.C., SNYDER, E.Y., YOO, J.J., FURT,H M.E., SOKER, S. and ATALA, A. (2007). Isolation of amniotic stem cell lines with potential for therapy. Nat. Biotechnol. 25(1): 100-106

DERRINGTON, E.A., DUFAY, N., RUDKIN, B.B. and BELIN, M.F. (1998). Human primitive neuroectodermal tumour cells behave as multipotent neural precursors in response to FGF2. Oncogene 17: 1663-1672.

DOETSCH, F. (2003). A niche for adult neural stem cells. Curr. Opin. Genet. Dev. 13(5): 543-550.

DUFAY, N., BELIN, M.F., CONFAVREUX, C., TOURAINE-MOULIN, F. and DERRINGTON, EA. (1994). Cholera toxin beta subunit induces the differentiation of human medullobastoma cell line DEV in a neuronal pathway. Eur. J. Neurosci. 6: 1633-1640.

EGLITIS, M.A. and MEZEY, E. (1997). Hematopoietic cells differentiate into both microglia and macroglia in the brains of adult mice. Proc. Natl. Acad. Sci. USA 94(8): 4080-4085. 
ENDE, N., WEINSTEIN, F., CHEN, R. and ENDE, M. (2000). Human umbilical cord blood effect on sod mice (amyotrophic lateral sclerosis). Life Sci. 67(1): 53-59.

ENGLISH, D., KLASKO, S.K. and SANBERG, PR. (2006). Elusive mechanisms of "stem cell"-mediated repair of cerebral damage. Exp. Neurol. 199: 10-15.

ERDO, F., BUHRLE, C., BLUNK, J, HOEHN, M., XIA, Y., FLEISCHMANN, B., FOCKING, M., KUSTERMANN, E., KOLOSSOV, E., HESCHELER, J., HOSSMANN, K.A. and TRAPP, T. (2003). Host-dependent tumorigenesis of embryonic stem cell transplantation in experimental stroke. J. Cereb. Blood Flow. Metab. 23(7): 780-785.

ERENIEV, S.I., SEMCHENKO, V.V., SYSHEVA, E.V., BOGDASHIN, I.V., SHAPOVALOVA, V.V., KHIZHNYAK, A.S. and GASANENKO, L.N. (2005). Effect of allo- and xenotransplantation of embryonic nervous tissue and umbilical cord blood-derived stem cells on structural and functional state of cerebral cortex of albino rats in posttraumatic period. Bull. Exp. Biol. Med. 140(5): 612 615.

ERIKSSON, P.S., PERFILIEVA, E., BJORK-ERIKSSON, T., ALBORN, A.M., NORDBORG, C., PETERSON, D.A. and GAGE, F.H. (1998). Neurogenesis in the adult human hippocampus. Nat. Med. 4(11): 1313-1317.

ESCOLAR, M.L., POE, M.D., PROVENZALE, J.M., RICHARDS, K.C., ALLISON, J., WOOD, S., WENGER, D.A., PIETRYGA, D., WALL, D., CHAMPAGNE, M., MORSE, R., KRIVIT, W. and KURTZBERG, J. (2005). Transplantation of umbilical-cord blood in babies with infantile Krabbe's disease. N. Engl. J. Med. 352(20): 2069-2081.

ESCOLAR, M.L., POE, M.D., MARTIN, H.R. and KURTZBERG, J. (2007). A staging system for infantile Krabbe disease to predict outcome after unrelated umbilical cord blood transplantation. Pediatrics 118: 879-889.

EVANS, M.J. and KAUFMAN, M.H. (1981). Establishment in culture of pluripotential cells from mouse embryos. Nature 292(5819): 154-156.

FAN, C.G., ZHANG, Q.J., TANG, F.W., HAN, Z.B., WANG, G.S. and HAN, Z.C. (2005). Human umbilical cord blood cells express neurotrophic factors. Neurosci. Lett. 380(3): 322-325.

FERRARI, G., CUSELLA-DE ANGElis, G., COLETTA, M., PAOLUCCI, E., STORNAIUOLO, A., COSSU, G. and MAVILIO, F. (1998). Muscle regeneration by bone marrow-derived myogenic progenitors. Science 279(5356): 15281530.

FUJIKAWA, T., OH, S.H., PI, L., HATCH, H.M., SHUPE, T. and PETERSEN, B.E. (2005). Teratoma formation leads to failure of treatment for type I diabetes using embryonic stem cell-derived insulin-producing cells. Am. J. Pathol. 166(6): 1781-1791.

GARBUZOVA-DAVIS, S., WILLING, A.E., ZIGOVA, T., SAPORTA, S., JUSTEN, E.B., LANE, J.C., HUDSON, J.E., CHEN, N., DAVIS, CD. and SANBERG, P.R. (2003). Intravenous administration of human umbilical cord blood cells in a mouse model of amyotrophic lateral sclerosis: distribution, migration, and differentiation. J. Hematother. Stem Cell Res. 12(3): 255-270.

GLUCKMAN, E., BROXMEYER, H.A., AUERBACH, A.D., FRIEDMAN, H.S., DOUGLAS, G.W., DEVERGIE, A., ESPEROU, H., THIERRY, D., SOCIE, G. and LEHN, P. (1989). Hematopoietic reconstitution in a patient with Fanconi's anemia by means of umbilical-cord blood from an HLA-identical sibling. N. Engl. J. Med. 321(17): 1174-1178.

GORNICKA, E., JANOWSKI, M., JURGA, M., HABICH, A., WANACKA, E. and LUKOMSKA, B. (2005). Transplantation of human umbilical cord blood-derived neural progenitors (HUCB-NPs) improves functional recovery after ouabain lesion in the rat striatum. Acta Neurobiol. Exp. 65: 50.

GORNICKA, E., JANOWSKI, M., JURGA, M., HABICH, A., WANACKA, E. and LUKOMSKA, B. (2006). Human umbilical cord blood-derived neural progenitors (HUCB-NPs) effects on functional recovery from long-lasting motor deficits following ouabain lesion of the rat brain. Behav. Pharm. 17: 555.

GUAN, K., NAYERNIA, K., MAIER, L.S., WAGNER, S., DRESSEL, R., LEE, J.H., NOLTE, J., WOLF, F., LI, M., ENGEL, W. and HASENFUSS, G. (2006). Pluripotency of spermatogonial stem cells from adult mouse testis. Nature 440(7088): 1199-1203.

HABICH, A., JURGA, M., MARKIEWICZ, I., LUKOMSKA, B., BANY-LASZEWICZ, U. and DOMANSKA-JANIK, K. (2006). Early appearance of neural progenitors in human cord blood mononuclear cells cultured in vitro. Exp. Hematology 34 : 914-925.

HARRIS, R.G., HERZOG, E.L., BRUSCIA, E.M., GROVE, J.E., VAN ARNAM, J.S. and KRAUSE, D.S. (2004). Lack of a fusion requirement for development of bone marrow-derived epithelia. Science 305(5680): 90-93.

HAYASHI, J., TAKAGI, Y., FUKUDA, H., IMAZATO, T., NISHIMURA, M., FUJIMOTO, M., TAKAHASHI, J., HASHIMOTO, N. and NOZAKI, K. (2006). Primate embryonic stem cell-derived neuronal progenitors transplanted into ischemic brain. J. Cereb. Blood Flow. Metab. 26(7): 906-914

HERMANN, A., GASTL, R., LIEBAU, S., POPA, M.O., FIEDLER, J., BOEHM, B.O., MAISEL, M., LERCHE, H., SCHWARZ, J., BRENNER, R. and STORCH, A. (2004). Efficient generation of neural stem cell-like cells from adult human bone marrow stromal cells. J. Cell Sci.117: 4411-4422.

HSIEH, J. and GAGE, F.H. (2004). Epigenetic control of neural stem cell fate. Curr. Opin. Genet. Dev. 14(5): 461-469.

JANG, Y.Y., COLLECTOR, M.I., BAYLIN, S.B., DIEHL, A.M. and SHARKIS, S.J. (2004). Hematopoietic stem cells convert into liver cells within days without fusion. Nat. Cell Biol. 6(6): 532-539.

JANOWSKI, M., LUKOMSKA, B., KOZLOWSKA, H. and DOMANSKA-JANIK, K. (2004). Intra-carotic administration of neural progenitors derived from human umbilical cord blood mononuclear fraction gives robust behavioral recovery in ouabain model of stroke. Exp. Neurology 187: 210.

JANOWSKI, M, KOZLOWSKA, H., JURGA, M., HABICH, A., WANACKA, E., LUKOMSKA, B. and DOMANSKA-JANIK, K (2006a). Early migration of human umbilical cord blood cells transplanted into rat brain. Neurosc. Res. 55 Supplement 1, 219

JANOWSKI, M., KOZLOWSKA, H., JURGA, M., WANACKA, E., DOMANSKAJANIK, K. and LUKOMSKA, B. (2006b). Xenotransplantation of human umbilical cord blood neural stem cells (HUCB-NSC) into immunosuppressed rat brain. Acta Neurobiol. Exp. 66(4): 402-403.

JIANG, Y., JAHAGIRDAR, B.N., REINHARDT, R.L., SCHWARTZ, R.E., KEENE, C.D., ORTIZ-GONZALEZ, X.R., REYES, M., LENVIK, T., LUND, T., BLACKSTAD, M., DU J., ALDRICH, S., LISBERG, A., LOW, W.C., LARGAESPADA, D.A. and VERFAILLIE, C.M. (2002). Pluripotency of mesenchymal stem cells derived from adult marrow. Nature 418(6893): 41-49.

JURGA, M. and DOMANSKA-JANIK, K. (2004). Neurospheres of human umbilical cord blood derived neural stem cells - in vitro model of stem cell niche. FENS Forum Abstracts A040.16.

JURGA, M., BUZANSKA, L., MALECKI, M., HABICH, A. and DOMANSKA-JANIK, K. (2006a). Function of ID1 protein in human cord blood-derived neural stemlike cells. J. Neurosci. Res. 84(5): 993-1002.

JURGA, M., MARKIEWICZ, I., SARNOWSKA, A., BUZANSKA, L., LUKOMSKA, B. and DOMANSKA-JANIK, K. (2006b). Preconditioning of human neural stem cells in low serum medium increases their differentiation into neurons. $J$. Neurosci. Res. 83: 627-631.

KELLY, S., BLISS, T.M., SHAH, A.K., SUN, G.H., MA, M., FOO, W.C., MASEL, J., YENARI, M.A., WEISSMAN, I.L., UCHIDA, N., PALMER, T. and STEINBERG, G.K. (2004). Transplanted human fetal neural stem cells survive, migrate, and differentiate in ischemic rat cerebral cortex. Proc. Natl. Acad. Sci. USA101(32): 11839-11844.

KOGLER, G., SENSKEN, S., AIREY, J.A., TRAPP, T., MUSCHEN, M., FELDHAHN, N., LIEDTKE, S., SORG, R.V., FISCHER, J., ROSENBAUM, C., GRESCHAT, S., KNIPPER, A., BENDER, J., DEGISTIRICI, O., GAO, J., CAPLAN, A.I., COLLETTI, E.J., ALMEIDA-PORADA, G., MULLER, H.W., ZANJANI, E. and WERNET, P. (2004). A new human somatic stem cell from placental cord blood with intrinsic pluripotent differentiation potential. J. Exp. Med. 200(2): 123-135.

KOMITOVA, M., MATTSSON, B., JOHANSSON, B.B. and ERIKSSON, P.S. (2005). Enriched environment increases neural stem/progenitor cell proliferation and neurogenesis in the subventricular zone of stroke-lesioned adult rats. Stroke 36(6): 1278-1282.

KORBLING, M., KATZ, R.L., KHANNA, A., RUIFROK, A.C., RONDON, G., ALBITAR, M., CHAMPLIN, R.E. and ESTROV, Z. (2002). Hepatocytes and epithelial cells of donor origin in recipients of peripheral-blood stem cells. N. Engl. J. Med. 346(10): 738-746.

KOZLOWSKA, H., MARKIEWICZ, I., HABICH, A., LUKOMSKA. B. and DOMANSKA - JANIK, K. (2005). Neural Stem-like Cells from human cord blood acquire the phenotype of neural cells after transplantation into neonatal rat brain. $J$. Neurochem. 94 supplement 2, 248.

KOZLOWSKA, H., JANOWSKI, M., ZIEMKA-NALECZ, M., WANACKA, E. and LUKOMSKA, B. (2006). New model of experimental stroke in rats: cellular networking in response to injury. Acta Neurobiol. Exp. 66(4): 402. 
KOZLOWSKA, H., JABLONKA, J., JANOWSKI, M., JURGA, M., KOSSUT, M. and DOMANSKA-JANIK, K. (2007). Transplantation of a novel human cord bloodderived neural stem-like cell line in rat model of cortical infarct. Stem Cell and Dev. 16: 481-488.

KRAUSE, D.S., THEISE, N.D., COLLECTOR, M.I., HENEGARIU, O., HWANG, S., GARDNER, R., NEUTZEL, S. and SHARKIS, S.J. (2001). Multi-organ, multilineage engraftment by a single bone marrow-derived stem cell. Cel/105(3): 369-377.

KUCIA, M., ZUBA-SURMA, E., WYSOCZYNSKI, M., DOBROWOLSKA, H., RECA, R., RATAJCZAK, J. and RATAJCZAK, M.Z. (2006). Physiological and pathological consequences of identification of very small embryonic like (VSEL) stem cells in adult bone marrow. J. Physiol. Pharmacol. 57 Supplement 5: 5-18.

KUH, S.U., CHO, Y.E., YOON, D.H., KIM, K.N. and HA, Y. (2005). Functional recovery after human umbilical cord blood cells transplantation with brainderived neutrophic factor into the spinal cord injured rat. Acta Neurochir. (Wien) 147(9): 985-992.

LAGASSE, E., CONNORS, H., AL-DHALIMY, M., REITSMA, M., DOHSE, M., OSBORNE, L., WANG, X., FINEGOLD, M., WEISSMAN, I.L. and GROMPE, M. (2000). Purified hematopoietic stem cells can differentiate into hepatocytes in vivo. Nat. Med. 6(11): 1229-1234.

LAUGHLIN, M.J., BARKER, J., BAMBACH, B., KOC, O.N., RIZZIERI, D.A., WAGNER, J.E., GERSON, S.L., LAZARUS, H.M., CAIRO, M., STEVENS, C.E., RUBINSTEIN, P. and KURTZBERG, J. (2001) Hematopoietic engraftment and survival in adult recipients of umbilical-cord blood from unrelated donors. $N$. Engl. J. Med. 344(24): 1815-1822.

LINDVALL, O. and KOKAIA, Z. (2004). Recovery and rehabilitation in stroke: stem cells. Stroke 11 Supplement 1: 2691-2694.

LIU, H.Y., ZHANG, Q.J., LI, H.J. and HAN ZC. (2006). Effect of intracranial transplantation of CD34+ cells derived from human umbilical cord blood in rats with cerebral ischemia. Chin. Med. J. (Engl) 119(20): 1744-1748.

LU, D., SANBERG, P.R., MAHMOOD, A., LI, Y., WANG, L., SANCHEZ-RAMOS, J. and CHOPP, M. (2002). Intravenous Administration of Human Umbilical Cord Blood Reduces Neurogical Deficit in the Rat After Traumatic Brain Injury. Cell Transplantation 11: 275-281

MC GUCKIN, C.P., FORRAZ, N., ALLOUARD, Q. and PETTENGELL, R. (2004). Umbilical cord blood stem cells can expand hematopoietic and neuroglial progenitors in vitro. Exp. Cell Res. 295(2): 350-359.

MEIER, C., MIDDELANIS, J., WASIELEWSKI, B., NEUHOFF, S., ROTH-HAERER, A., GANTERT, M., DINSE, H.R., DERMIETZEL, R. and JENSEN, A. (2006). Spastic paresis after perinatal brain damage in rats is reduced by human cord blood mononuclear cells. Pediatr. Res. 59(2): 244-249.

MELTON, D.A. and COWAN, C. (2004). "Stemness": definitions, Criteria, and Standards. In Lanza R., Gerhart J., Hogan B., Melton D., Pedersen R., Thomson J., West M. (eds) Handbook of Stem Cells, vol 1. Elsevier AP 25-31.

NAN, Z., GRANDE, A., SANBERG, C.D., SANBERG, P.R. and LOW, W.C. (2005). Infusion of human umbilical cord blood ameliorates neurologic deficits in rats with hemorrhagic brain injury. Ann. N. Y. Acad. Sci. 1049: 84-96.

NEWCOMB, J.D., AJMO, C.T JR., SANBERG, C.D., SANBERG, P.R., PENNYPACKER, K.R. and WILLING, A.E. (2006). Timing of cord blood treatment after experimental stroke determines therapeutic efficacy. Cell Transplant. 15(3): 213-223.

NEWMAN, M.B., WILLING, A.E., MANRESA, J.J., SANBERG, C.D. and SANBERG, PR. (2006). Cytokines produced by cultured human umbilical cord blood (HUCB) cells: implications for brain repair. Exp. Neurol. 199(1): 201-208.

NYSTEDT, J., MÄKINEN, S., LAINE, J. and JOLKKONEN, J. (2006). Human cord blood CD34+ cells and behavioural recovery following focal cerebral ischemia in rats. Acta Neurobiol. Exp. 66: 293-300.

ORLIC, D., KAJSTURA, J., CHIMENTI, S., LIMANA, F., JAKONIUK, I., QUAINI, F., NADAL-GINARD, B., BODINE, D.M., LERI, A. and ANVERSA, P. (2001). Mobilized bone marrow cells repair the infarcted heart, improving function and survival. Proc. Natl. Acad. Sci. USA 98(18): 10344-10349.

PAN, Y., NASTAV, J.B., ZHANG, H., BRETTON, R.H., PANNETON, W.M. and BICKNESE, A.R. (2005). Engraftment of freshly isolated or cultured human umbilical cord blood cells and the effect of cyclosporin A on the outcome. Exp. Neurol. 192(2): 365-372.

POULSOM, R., ALISON, M.R., FORBES, S.J. and WRIGHT, N.A. (2002). Adult stem cell plasticity. J. Pathol. 197(4): 441-456.

RAO, M. (2004). Conserved and divergent paths that regulate self-renewal in mouse and human embryonic stem cells. Dev. Biol. 275: 269-286.

SANCHEZ-RAMOS, J., SONG, S., CARDOZO-PELAEZ, F., HAZZI, C., STEDEFORD, T., WILLING, A., FREEMAN, T.B., SAPORTA, S., JANSSEN, W., PATEL N., COOPER, D.R. and SANBERG, P.R. (. 2000). Adult bone marrow stromal cells differentiate into neural cells in vitro. Exp. Neurol. 164(2): 247-256.

SAPORTA, S., KIM, J.J., WILLING, A.E., FU, E.S., DAVIS, C.D. and SANBERG, P.R. (2003). Human umbilical cord blood stem cells infusion in spinal cord injury: engraftment and beneficial influence on behavior. J. Hematother. Stem Cell Res. 12(3): 271-278.

SATO, N., MEIJER, L. and SKALTSOUNIS, L. (2004). Maintenance of pluripotency in human and mouse embryonic stem cells through activation of Wnt signaling by a pharmacological GSK-3-specific inhibitor. Nature Med. 10: 55-63.

SCHEFFLER, B., EDENHOFER, F. and BRUSTLE, O. (2006). Merging fields: stem cells in neurogenesis, transplantation, and disease modeling. Brain Pathol. 16(2): 155-68.

SHERLEY, J.L. (2002). Asymmetric cell kinetics genes: the key to expansion of adult stem cells in culture. Stem Cel/s 20(6): 561-572.

SINGH, S.K., CLARKE, I.D., HIDE, T. and DRIKS, P.B. (2004). Cancer stem cells in nervous system tumors et al. Oncogene 23: 7267-7273.

SUN, W., BUZANSKA, L., DOMANSKA-JANIK, K., SALVI, R.J. and STACHOWIAK, M.K. (2005). Voltage-sensitive and ligand-gated channels in differentiating neural stem cells isolated from the nonhematopoietic fraction of human umbilical cord blood. Stem Cells 23: 931-945.

TABAR, V., PANAGIOTAKOS, G., GREENBERG, E.D., CHAN B.K., SADELAIN, M., GUTIN, P.H. and STUDER, L. (2005). Migration and differentiation of neural precursors derived from human embryonic stem cells in the rat brain. Nat. Biotechnol. 23(5): 601-606.

TAGOH, H., SCHEBESTA, A., LeFEVRE, P., WILSON, N., HUME, D., BUSSLINGER, M. and BONIFER, C. (2004). Epigenetic silencing of the C-fms locus during $B$-lymphopoiesis occurs in discrete steps and is reversible. EMBO J. 23(21): 4275-4285.

TAGUCHI, A., SOMA, T., TANAKA, H., KANDA, T., NISHIMURA, H., YOSHIKAWA, H., TSUKAMOTO, Y., ISO, H., FUJIMORI, Y., STERN, D.M., NARITOMI, H. and MATSUYAMA, T. (2004). Administration of CD34+ cells after stroke enhances neurogenesis via angiogenesis in a mouse model. J. Clin. Invest. 114(3): 330338.

TERSKIKH, A.V., EASTERDAY, M.C., LI, L., HOOD, L., KORNBLUM, H.I., GESCHWIND, D.H. and WEISSMAN, I.L. (2001). From hematopoiesis to neuropoiesis: evidence of overlapping genetic programs. Proc. Natl. Acad. Sci. USA 98(14): 7934-7939.

THOMSON, J.A., ITSKOVITZ-ELDOR, J., SHAPIRO, S.S., WAKNITZ, M.A., SWIERGIEL, J.J., MARSHALL, V.S. and JONES, J.M. (1998). Embryonic stem cell lines derived from human blastocysts. Science. 282(5391): 1145-1147.

VENDRAME, M., CASSADY, J., NEWCOMB, J., BUTLER, T., PENNYPACKER, K.R., ZIGOVA, T., SANBERG, C.D., SANBERG, P.R. and WILLING, AE. (2004). Infusion of human umbilical cord blood cells in a rat model of stroke dose-dependently rescues behavioral deficits and reduces infarct volume. Stroke 35(10): 2390-2395.

WALCZAK, P., CHEN, N., HUDSON, J.E., WILLING, A.E., GARBUZOVA-DAVIS, S.N., SONG, S., SANBERG, P.R, SANCHEZ-RAMOS, J., BICKFORD, P.C. and ZIGOVA, T. (2004). Do hematopoietic cells exposed to a neurogenic environment mimic properties of endogenous neural precursors? J. Neurosci. Res. 76(2): 244-254.

WILLING, A.E., LIXIAN, J., MILLIKEN, M., POULOS, S., ZIGOVA, T., SONG, S., HART, C., SANCHEZ-RAMOS, J. and SANBERG, PR. (2003). Intravenous versus intrastriatal cord blood administration in a rodent model of stroke. $J$. Neurosci. Res. 73(3): 296-307.

WILMUT, I., SCHNIEKE, A.E., MCWHIR, J., KIND, A.J. and CAMPBELL, K.H. (1997). Viable offspring derived from fetal and adult mammalian cells. Nature 385(6619): 810-813

WOODBURY, D., SCHWARZ, E.J., PROCKOP, D.J. and BLACK, I.B. (2000). Adult rat and human bone marrow stromal cells differentiate into neurons. J. Neurosci. Res. 61(4): 364-370. 
WURMSER, A.E., NAKASHIMA, K., SUMMERS, R.G., TONI, N., D'AMOUR, K.A., LIE, D.C. and GAGE, F.H. (2004). Cell fusion-independent differentiation of neural stem cells to the endothelial lineage. Nature. 430(6997): 350-356.

$\mathrm{XI}, \mathrm{R}$. and XIE, T. (2005). Stem cell self-renewal controlled by chromatin remodeling factors. Science 310(5753): 1487-1489.

XIAO, J., NAN, Z., MOTOOKA, Y. and LOW, WC. (2005). Transplantation of a novel cell line population of umbilical cord blood stem cells ameliorates neurological deficits associated with ischemic brain injury. Stem Cells Dev.14(6): 722-733.

YOON, Y.S., WECKER, A., HEYD, L., PARK, J.S., TKEBUCHAVA, T., KUSANO, K., HANLEY, A., SCADOVA, H., QIN, G., CHA, D.H., JOHNSON, K.L., AIKAWA R., ASAHARA, T. and LOSORDO, D.W. (2005). Clonally expanded novel multipotent stem cells from human bone marrow regenerate myocardium after myocardial infarction. J. Clin. Invest. 115(2): 326-338.

ZANDONELLA, C. (2005). The first wave. Nature 435: 877-878.

ZHAO, Y., GLESNE, D. and HUBERMAN, E. (2003). A human peripheral blood monocyte-derived subset acts as pluripotent stem cells. Proc. Natl. Acad. Sc.i USA 100(5):2426-2431.

ZIGOVA, T., PENCEA, V., SANBERG, P.R. and LUSKIN, M.B. (2000). The properties of hNT cells following transplantation into the subventricular zone of the neonatal forebrain. Exp. Neurol. 163(1): 31-38.

ZIGOVA, T., SONG, S., WILLING, A.E., HUDSON, J.E., NEWMAN, M.B., SAPORTA, S., SANCHEZ-RAMOS, J. and SANBERG, PR. (2002). Human umbilical cord blood cells express neural antigens after transplantation into the developing rat brain. Cell Transplant. 11(3): 265-274.

\section{Related, previously published Int. J. Dev. Biol. articles}

See our recent Special Issue Developmental Biology in Poland edited by Kloc, Maleszewski and Tarkowski at: http://www.ijdb.ehu.es/web/contents.php?vol=52\&issue=2-3

See our Special Issue Mammalian Reproduction \& Development in honor of Anne McLaren and edited by Brigid Hogan at: http://www.ijdb.ehu.es/web/contents. php?vol=45\&issue=3

Stem cells for the replacement of inner ear neurons and hair cells

Rodrigo Martinez-Monedero and Albert S.B. Edge

Int. J. Dev. Biol. (2007) 51: 655-661

Pax7 identifies neural crest, chromatophore lineages and pigment stem cells during zebrafish development Ana M Lacosta, Jesús Canudas, Cristina González, Pedro Muniesa, Manuel Sarasa and Luis Domínguez Int. J. Dev. Biol. (2007) 51: 327-331

Migration of neural crest-derived enteric nervous system precursor cells to and within the gastrointestinal tract Alan J. Burns

Int. J. Dev. Biol. (2005) 49: 143-150

Distinct neural precursors in the developing human spinal cord

Sally Walder and Patrizia Ferretti

Int. J. Dev. Biol. (2004) 48: 671-674

Heparan sulfates isolated from adult neural progenitor cells can direct phenotypic maturation.

Hiram Chipperfield, Kuldip S Bedi, Simon M Cool and Victor Nurcombe

Int. J. Dev. Biol. (2002) 46: 661-670

From hematopoietic stem cells to neural stem cells S Bonilla, P Alarcon, R Villaverde, P Aparicio, A Silva, S Martinez Int. J. Dev. Biol. (2001) 45: S67-S68

Mammalian neural tube grafting experiments: an in vitro system for mouse experimental embryology.

D Echevarría, C Vieira and S Martínez

Int. J. Dev. Biol. (2001) 45: 895-902

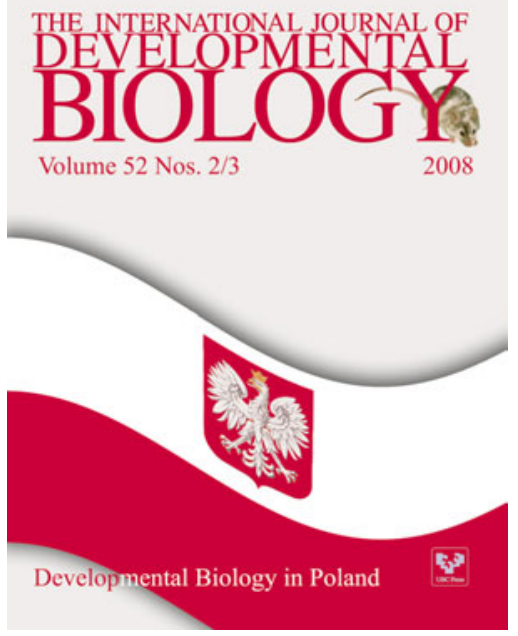

2006 ISI ${ }^{* \star}$ Impact Factor $=3.577^{\star *}$

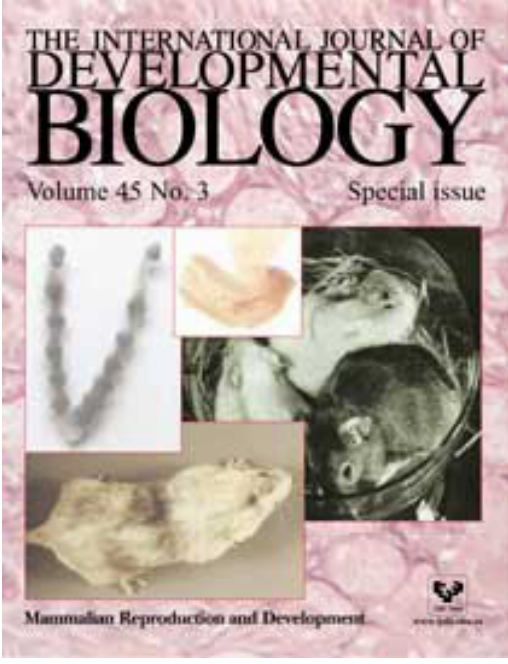

